\section{Ventanillas de Salud: defeating challenges in healthcare access for Mexican immigrants in the United States}

\author{
Ventanillas de Salud: desafíos en el acceso a servicios \\ de salud de inmigrantes mexicanos en EE.UU.
}

Received on August 19, 2019.

Accepted on March 3, 2020.

Published on March 10, 2020.

* Corresponding author: Valeria Marina Valle, e-mail valeria.valle@ibero.mx; vmvalle@gmail.com

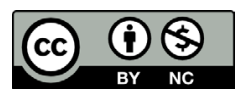

This work is licensed under a Creative Commons Attribution-NonCommercial 4.0 International License.
Valeria Marina Valle ${ }^{a *}$ (D) https://orcid.org/0000-0002-6797-6003 Wilma Laura Gandoy Vázquez ${ }^{\text {bid }}$ https://orcid.org/0000-0002-3679-1022 Karla Angélica Valenzuela Moreno ${ }^{a}$ (D) https://orcid.org/0000-0002-5024-3057

${ }^{a}$ Universidad Iberoamericana Ciudad de México (UIA), Departamento de Estudios Internacionales, Mexico City, Mexico, e-mail valeria.valle@ibero.mx; karla.valenzuela@ibero.mx

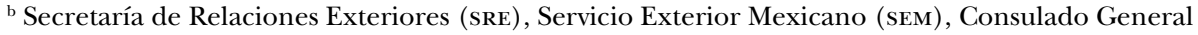
de México en San Francisco, California, United States, e-mail lgandoy@sre.gob.mx

\section{Abstract}

The 2010 Affordable Care Act (ACA) improved access to healthcare in the United States. However, immigrants - especially those undocumented- still faced difficulties, which have increased during the Trump administration. In order to bring access to health services to its nationals, the Mexican government has implemented the Health Windows Program (Ventanillas de Salud, or vDs). The article reviews changes in the U.S. healthcare system from the ACA to date, and assesses the role of vDs. The methodology is qualitative, consisting of a literature review, interviews with community leaders and Mexican government officials, and questionnaires sent to four vDs: Arizona, Florida, Idaho and Texas. Results show that vDs provide reliable and affordable access to basic healthcare services, and detection of chronic and non-communicable diseases, especially within undocumented immigrants. Public policy recommendations are offered based on these findings. Limitations of the study include the data collected, which is non-representative of all vDs.

Keywords: healthcare access; consulates; insurance; preventive care; early detection of chronic and non-communicable diseases; community health clinics; Ventanillas de Salud; Mexican immigrants in the United States.

\section{Resumen}

En 2010 el Affordable Care Act (ACA) brindó mayor acceso a la salud en Estados Unidos, pero los inmigrantes aún enfrentan dificultades, particularmente los indocumentados. Para brindar acceso a servicios de salud a sus connacionales,

CITATION: Valle, V. M., Gandoy, W. L. \& Valenzuela, K. A. (2020). Ventanillas de Salud: defeating challenges in healtcare access for Mexican immigrants in the United States. [Ventanillas de salud: desafíos en el acceso a servicios de salud de inmigrantes mexicanos en EE.Uu.]. Estudios Fronterizos, 21, e043. https://doi.org/10.21670/ref.2001043 
el gobierno mexicano creó el programa Ventanillas de Salud (VDS). El artículo analiza cambios en el sistema de salud de Estados Unidos a partir del ACA y el papel de las vDs. La metodología cualitativa incluye: revisión de literatura, entrevistas a líderes comunitarios y miembros del gobierno mexicano y cuestionarios enviados a cuatro vDs: Arizona, Florida, Idaho y Texas. Los resultados demuestran que las vDs proveen información confiable, acceso económico a servicios de salud, detección temprana de enfermedades crónicas y no transmisibles, especialmente para inmigrantes indocumentados. Se presentan recomendaciones de política pública basadas en evidencias. Las limitaciones radican en que los datos de las cuatro vDs no son representativos de todo el programa.

Palabras clave: acceso a la salud; consulados; seguro médico; atención preventiva; detección temprana de enfermedades crónicas no transmisibles; clínicas comunitarias; Ventanillas de Salud; inmigrantes mexicanos en EE.UU.

\section{Introduction}

It is estimated that more than 36 million people of Mexican origin live in the United States (U.S.), of which approximately 12 million were born in Mexico, 12 million are second generation migrants and 12 million belong to a third or subsequent generation (Hernández, 2015; Gzesh \& Schiavon, 2018). Of those 12 million first generation immigrants, 6 million are undocumented. Undocumented immigrants are the most vulnerable group when it comes to access to healthcare. According to Wendy Parmet:

Non-citizen immigrants are the canaries in the health care coal mine. Disproportionately poor, non-white, non-English speakers, and without access to the franchise, they are among the most vulnerable groups in the United States. Consequently, they are often the first to experience the gaps, inefficiencies, and conflicts in our healthcare system (Parmet, 2018).

In most states, undocumented immigrants in the U.S. do not have access to healthcare, but pay taxes. According to Becerra, Androff, Ayón and Castillo, "at the federal level undocumented immigrants tend to contribute more money in taxes than they consume services" (Becerra et al. 2012, p. 111).

Given the requirements of the Affordable Care Act (ACA) today, it is no surprise that the 2015 Census Bureau reported that only $38.3 \%$ of Mexicans had public insurance coverage (Barnett \& Vomovitsky, 2016), placing Mexicans and Hispanic communities in a worse situation than the non-hispanic white population. Furthermore, in 2014, only $38.8 \%$ of young Mexicans reported to "be in good health" (Rangel et al., 2016).

In a context in which not all documented and undocumented immigrants have access to Medicaid, nor are they able to purchase an affordable insurance policy from the Marketplace, healthcare services provided by the program Ventanillas de Salud (vDs) (Health Windows) of the Consulates of Mexico in collaboration with different agencies and community based clinics, although insufficient, become crucial. The services provided by VDS, can be divided into three categories: 1) they provide information and counseling, 2) they offer several free tests that often detect chronic diseases such as diabetes, and 3) they make referrals to communitarian health clinics. Counseling has to do with the following health issues: diabetes, obesity, hypertension, 
nutrition, sports, women's health, domestic violence, cancer, mental health, influenza, dental hygiene, drugs, heart diseases, reproductive health, prenatal care, eye care and occupational health. Tests administered by the vDs include blood pressure, weight and height, glycaemia, urine tests, HIV and other sexually transmitted diseases tests, tuberculosis, mammograms, vaccines against influenza and Zoster herpes, skin cancer, and odontology. Furthermore, one of the most crucial functions of the vDs is to build partnerships with community-based health clinics that might provide healthcare services at affordable prices (Instituto de los Mexicanos en el Exterior [IME], 2016). The government of Mexican President Andrés Manuel López Obrador, who took office in December 2018, has allocated 45 million Mexican pesos for their operation, 5 million more than the previous administration (Valdovinos, 2019). Despite the fact that this amount might not be large enough in U.S. dollars, in terms of the Mexican government spending, it indicates that the new administration is aware of the importance of the vDS program, especially in the context of the current anti-immigrant posture of the federal government of the United States and some local governments as well.

The aim of vDs' services is to prevent and even detect chronic diseases as well as to reduce the number of occasions in which uninsured immigrants have to use the emergency services at hospitals (Rangel et al., 2016, p. 97; IME, 2016). Prevention and early detection of chronic and non-communicable diseases is crucial especially in the context of the Trump administration, since there is a generalized founded fear among Hispanic immigrants of being deported if they provide their information at healthcare facilities. Martínez, Ruelas and Granger argue that fear of deportation has led "Mexican-origin families to evade services from government agencies, despite their children qualifying for them" (Martínez, et al., 2018, p. 189). This is so especially for first generation Mexicans, particularly undocumented ones, whose children were born in the United States. "Despite the fact that these children are American, their parents may refuse to take them to hospitals for fear of deportation" (Moya et al., 2013, p. 1008). However, consular practice shows that there are also migrants who do take advantage of the health services and referrals when they are advised to do so by a trusted person or institution. Furthermore, the "Public Charge Rule" promoted by the Trump administration (Department of Homeland Security v. New York, 2020), and its implications on immigration adjustment of status procedures, has made an increasing number of immigrants choose not to seek access to health services. Even though the policy change was not valid in 2018, at that time " $\mathrm{t}]$ he proposed changes to public charge policy [...] [were] already causing significant harm. Fear and confusion - known as the chilling effect- [were] causing people to disenroll from programs or forgo benefits to which they are eligible" (Protecting Immigrant Families, 2019). Fear and disenrollment from public services is not new, as it is evidenced here:

Some parents fear that enrolling children in programs will affect future chances at regularization, including family sponsorship or naturalization. The variability in the public charge assessment - in which applicants for permanent residency status must prove they will not be primarily dependent on the governmenthas led some families to avoid obtaining services for their children (Mendoza, 2009, and Park, 2011, cited in Castañeda \& Melo, 2014, p. 1895).

If immigrants cancel visits to the doctor, or do not take preventive health measures, not only can they end up at Emergency Rooms, but they can also affect others, including 
the non-immigrant population. For example, skipped vaccinations or treatments could provoke the spread of infectious diseases, creating a public health problem. Moreover, if patients avoid treatment for chronic diseases, this could cause potential problems in the future that could derive in more expensive and invasive care (Adams, 2018; Rangel et al., 2016, p. 98).

Uncertainty about immigration laws and anti-immigrant political discourses and sentiments cause stress not only to immigrants themselves, but also to their families on both sides of the border. A recent survey conducted by the American Psychological Association (APA) found that $45 \%$ of the adult population feel stressed by separation and deportation of migrant family members; the numbers rise up to $57 \%$ for Generation Z (APA, 2018, p. 3; Merriam-Webster, n.d.). In current times, mental health is also a highly relevant issue that some consulates in the United States — such as New York, Little Rock and Los Angeles- are now including within the services of their Health Windows as part of a pilot program (Consulado General en Nueva York, 2019; Consulado General en Little Rock, 2019).

Given this context, this article will make a first assessment about the impact of vDs, considering the political changes in the United States regarding healthcare access. In this sense, this article is composed of four main sections. The first one offers a background that explains how access to healthcare changed during the Obama and Trump administrations. The second one sheds light on the importance of the vDS program and community clinics to provide access to healthcare to Mexican immigrants in the United States. The third part brings results, discussion and analysis of statistics from 2015. The study conducted by Rangel et al. (2016) provides data on 50 vDs and the other one comprises surveys to four vDs conducted by the authors. Data is compared between these two sources. The fourth part includes conclusions and public policy recommendations as well as suggestions for further research on this topic.

\section{Methodology}

This is a study of qualitative nature that has been developed using primary and secondary sources. This is an important remark given that the qualitative investigation has no intention of establishing general laws through statistics, nor through representative samples. The purpose of a study of this sort is to give an initial explanation of how and why different phenomena occur (Rodríguez, 2014, pp. 7-21). From these conclusions, further investigations may be conducted.

First, in order to contextualize the relevance of the vDs, the authors reviewed information on access to healthcare services in the United States and changes on policies related to healthcare access. Afterwards, in order to understand how the Mexican population in the United States may have access to health services through the VDS, the authors retrieved information from a study conducted by Rangel et al. (2016), which gathers data from the 52 vDs in the United States for the year 2015. The results of this study have been compared with information the authors gathered through questionnaires sent in 2016 to the vDs of different Consulates of Mexico located in Arizona, Florida, Idaho and Texas, which serve seven U.s. states. In these questionnaires, the different vDs shared their global findings for the year 2015. 
The four states in which these consulates are located were mainly Republican supporters in the 2016 presidential elections. Despite this fact, it is important to underline that we will see that the vDs offer different types of services, some of them not available in other Windows, not as a response to the local policy regarding health. Rather, the services are defined by the consulate's budget, the type of health partnerships they establish, as well as the availability of consular staff, and trying to address the most pervasive health issues known within the Mexican population, such as diabetes. In order to shed light on the fact that the undocumented Mexican community in the United States is being fearful to look for different services such as health check-ups and of giving out their information, as they might trigger a deportation procedure, the authors also conducted interviews with Oscar Chacón, co-founder and executive director of Alianza Americas (formerly known as National Alliance of Latin American \& Caribbean Communities (NAlacc) and Judith Montenegro, Program Director of Latinos in the Deep South, Latino Commission on AIDs, North Carolina, in 2018 (O. Chacón, personal communication, October 7, 2014; J. Montenegro, personal communication, January 9, 2018; Consumer News and Business Channel [CNBC], 2018). Fear is experienced not only by adults, but also by children, as it will be analyzed below in more detail. Data has also been collected from testimonies of members of the Institute for Mexicans Abroad (Instituto de los Mexicanos en el Exterior [IME], 2016) in academic and other public events.

The information provided by consulates and the study by Rangel et al. (2016) supported the qualitative arguments of the authors, which were drawn from the literature review, the practical expertise in consular protection affairs of one of the coauthors, and testimonies derived from interviews. Furthermore, we argue that qualitative analyses are particularly important when studying vulnerable populations, in order to grasp the individual or group effects of public policies. After presenting both secondary and primary sources, conclusions reveal that services given by vDs provide reliable and affordable access to basic healthcare services for Mexican immigrants in the United States and are helpful to detect chronic and non-communicable diseases, especially within the Mexican undocumented population.

\section{Background: changes in Access to Healthcare during the Obama and Trump Administrations}

Mexican immigrants' access to healthcare in the United States changed after the ACA, also known as Obamacare, which was signed on March 23, 2010 and in plain execution by 2014 . The goals of this law were to: 1 ) increase the quality of health insurance, 2) lower the uninsured rate by expanding public and private insurance coverage and 3) reduce the costs of healthcare for individuals and the government (Obamacare Facts, 2018). In general terms, the Medicaid program was expanded and conditions were created in order to have different insurance options at more affordable prices.

Medicaid is an assistance program that serves low-income persons of any age. This program is managed by every state within federal guidelines; some of them had extended the coverage options for low-income citizens and documented immigrants and are known as "expansion states" (u.s. Department of Health and Human Services, 
2015). However, the documented immigrants have to wait for a five-year period in order to be eligible for Medicaid (Consejo Nacional de Población, 2012). In the meantime, they may purchase an insurance premium from any agency within what is called the "Marketplace", which offers not only competitive prices, but also the possibility to receive tax credits.

According to the Assistant Secretary for Planning and Evaluation (ASPE) from the Department of Health and Human Services of the United States, from 2014 to 2015 , the so called "expansion states" experienced a $9.2 \%$ reduction in the number of uninsured adults versus 7.9\% from "non-expansion states" (Office of the Assistant Secretary for Planning and Evaluation [ASPE], 2016, pp. 1-2). Although this was a positive effect of the law, Obamacare did not mean good news for everyone. Despite the important contributions that the ACA has had in terms of reducing the total number of uninsured persons in the United States, many documented and undocumented immigrants have been left without any possibility of getting an affordable premium from the insurance agencies. This means that those holding a working visa (H1 or H2, for example), who have the Deferred Action for Childhood Arrivals (DACA), or simply who are undocumented — and consequently don't have a Social Security Number- don't have an affordable path to receive health services; in other words, they can get a health insurance policy but not at a preferential rate (ASPE, 2016, pp. 1-2).

According to Chen et al., the ACA did not eliminate racial and ethnic disparities in healthcare access and utilization:

Relatively smaller declines in uninsured rates among Latinos may be explained by the fact that recent Latino immigrants are more likely to live in states that are not participating in the Medicaid expansion as well as poor outreach to the Latino community regarding the ACA eligibility, subsidies, and enrollment. Important progress among Latinos, however, is observed in this short-term analysis of the ACA implementation in terms of fewer delays and a lower probability of forgoing health care among Latinos who were eligible. These results suggest that the ACA has the potential to reduce and eliminate racial and ethnic disparities if present trends continue (Chen, et al., 2016, p. 142).

Nevertheless, these results could vary from state to state, depending on whether the state analyzed participation in the Medicaid expansion or not. For example, according to Kemmick et al. (2019), California operates the largest Medicaid program in the country (called Medi-Cal), having a record coverage of $42 \%$ (or over 4 million) of all children. However, the rates of PCP acceptance of Medicaid coverage is very low, probably due to low Medi-Cal reimbursement rates (Kemmick et al., 2019).

Moreover, Ortega et al. (2017) argue that a national study of adults found that health insurance coverage improved after the implementation of the ACA for non-Latino whites, non-Latino blacks, and Latinos. However, inequities in insurance coverage and utilization of services still persisted. A separate study found that coverage improved for all Latino adults, but Latinos with heritages from Mexico and Central America had lower odds of being insured between 2011 and 2015, when compared with nonLatino whites. These disparities were not reduced by the ACA insurance expansion. In order to illustrate this, Ortega et al. explain that in 2011 the uninsurance rate among Latino youth was $10 \%$, or 2.5 times the rate for white youth (4\%) and that by 2015 
uninsurance among Latino youth had decreased to $6 \%$, but was still three times that of white youth (2\%) (Ortega et al., 2017).

When President Donald Trump took office, he had managed to make a strong argument about healthcare benefits being a pull factor for immigrants, despite statistical facts against it. According to the Associated Press, based on a study from the Pew Research Center:

Hispanics are more than three times as likely to go without health insurance as are their white counterparts. Whites represented $63 \%$, or 3.8 million, of those who signed up for ACA plans in 2015 compared to $15 \%$, or just under a million Hispanics, according to the Centers for Medicare and Medicaid Services. The reasons vary, but some have always feared deportation, regardless of who is in office (Kennedy, 2018).

It is important to mention that on January 25, 2017, President Donald Trump issued an executive order signaling that those immigrants that "have abused any program related to receipt of public benefit" will be subject to deportation (White House, 2017). On August 14, 2019, the U.s. Department of Homeland Security published the final rule regarding the Inadmissibility on Public Charge Grounds, which came into effect nationwide on January 28, 2020. This final rule determines the factors that will be considered when analyzing if someone is likely to become a public charge in the future, making this person ineligible for admission or adjustment of status (Luthi, 2020). The public benefits considered in the public charge inadmissibility determinations include receiving assistance for 12 months in a three year period through cash benefit programs, food stamps, housing and rental assistance and federally funded Medicaid (U.s. Citizen and Immigration Services, 2019). Furthermore, in earlier attempts to relate healthcare with the so-called "migration crisis", the Health and Human Services Department announced it would take up to $\$ 385$ million dollars from healthcare programs and spend them in migrant children accommodation (U.s. Department of Health and Human Services, 2019).

In addition, in October and December 2017, President Trump, through executive orders, made modifications to the ACA. In December, he signed the Tax Cuts and Jobs Act, which repealed the Obamacare tax on those who were uninsured. Consequently, the Congressional Budget Office (сво) estimated that 13 million people were going to drop coverage. Therefore, healthcare costs would rise because there would be fewer healthy people paying premiums. Thus, fewer people would get preventive care or treatment for chronic diseases (Amadeo, 2018). In sum, healthcare options for all immigrant groups — regardless of their immigration status - are at risk of shrinking during the Trump administration.

In a harsh political environment that targets the immigrant community in different ways, prevention is crucial, especially in relation to chronic and non-communicable diseases, which are one of the most important health problems suffered by Mexican immigrants in the United States. Furthermore, during the Trump administration, it is not only fear that prevents immigrants from going to the doctor, but also changes to the ACA that are increasing the prices of insurance policies. Additionally, undocumented parents with American-born children, may fear to go to hospitals and provide information that could be used to deport them. 


\section{Access to Healthcare: a Relevant Issue for Both Countries}

The right to health is considered a human right at international conventions, signed both by Mexico and the United States. As originally set forth in the 1948 Universal Declaration of Human Rights by the United Nations (UN), every person is entitled to a universal set of basic rights, (General Assembly, 1948, articles 2 and 7). Moreover, in relation to the rights of international migrants, "no distinction shall be made on the basis of the political, jurisdictional or international status of the country or territory to which a person belongs" (General Assembly, 1948, article 2). The right to health includes aspects of wellbeing such as food and housing, medical care and social security; priority is given to maternal and child health (General Assembly, 1948, article 25). The same principals are included at the International Covenant on Economic, Social, and Cultural Right, signed in 1966, related to the right of all persons to the "highest attainable standard of physical and mental health" together with an adequate living standard; it is the responsibility of the State involved to guarantee these rights (Office of the High Commissioner for Human Rights [онсHR], 1966, articles 11 and 12). Independently of migratory status, every individual has the right to health (General Assembly, 1948).

The UN 2030 Agenda's 17 Sustainable Development Goals (sDGs), include goals and targets related to improving standards of human migration processes, including health and safety standards for migrants (Mosler et al., 2018, p. 10). sDGs also focus on the reduction of inequalities within and among countries (General Assembly, 2015), in part to be achieved through target 10.7: the "orderly, safe, regular and responsible migration and mobility of people, including through the implementation of planned and well-managed migration policies" (General Assembly, 2015). un leaders, convened in 2016, in relation to target an orderly, safe and regular migration compact, proposed a framework to guide migration responses, with the aim of protecting migrants' health and security. This compact was approved in Marrakech in December, 2018.

The Global Compact for Safe, Orderly and Regular Migration confirmed a worldwide partnership that highlights protection of the migrant's right to health and services and it gives priority to vulnerable groups (UN, 2018). The Compact is rooted in the evidence that migration, when conducted in an orderly and safe way, can drive sustainable development for the countries of origin, transit, and destination (UN, 2018).

At a regional level, the World Health Organization (wHO) has prioritized migrants' health, and has highlighted the persistent problem of high variability in attention and access to health systems by migrants between nations (Pan American Health Organization [PAHO], 2018).

At a bilateral level, unlike traditional models of Nation-States confined by physical or juridical borders, populations are highly mobile, and so are diseases. A binational community — such as Mexicans and Mexican-Americans_- poses challenges that are also binational and should be dealt with as such. Healthcare, whether physical or mental, is an important factor that affects populations on both sides of the border and should be addressed by both governments and civil society. Given the intense border mobility and interconnection patterns that American and Mexican populations share, healthcare should also be mobile. Given barriers to access healthcare services faced by Mexican immigrants in the United States, especially by undocumented ones, Mexican Consulates in the United States become the most suitable institution to achieve this goal. Given the need of having a form of identification, many Mexican nationals in the United States 
visit their Consulates, and during these visits the vDs gets to know the most common health issues of those who have approached them. Thus, within the limit of their budgets and the partnerships they achieve for the vDs, consulates are able to tailor programs specifically for their communities, regardless of immigration status.

Another issue that may affect access to healthcare, both in Mexico and in the United States is the fact that Mexican and American health systems present asymmetries. As explained by Valle and Ortiz (2015), most healthcare services in the United States are private, while in Mexico citizens without insurance can be assisted through a range of public institutions, such as the Mexican Institute of Social Security (IMSs), the Institute of Social Security for the State's Workers (ISSSTE) and the recently created Institute for Health and Well-being (Insabi), which replaced the Popular Insurance Program (Seguro Popular). Although this is true, according to Gómez et al. (2011), in Mexico, people with public insurance also utilize private services, usually outpatient services. Reports from the Organization for Economic Cooperation and Development (OECD) state that in Mexico, out-of pocket payment represented around $40 \%$ of all health spending in year 2019 (OECD, 2019a). Furthermore, the investment of the GDP in health services is very uneven for both countries. While Mexico only invests 2.7\%, the United States invests $16.9 \%$, making it the country with the highest investment in health (oECD, 2019b).

Notwithstanding such an important investment, undocumented immigrants are not the priority of the U.s. government, and thus it has not been able to fully cover their health needs. Given this fact, non-governmental organizations that have not discriminated against the undocumented when providing care, have gained a salient role in healthcare provision (Valle \& Ortiz, 2015, p. 109). Access to healthcare for undocumented immigrants is a relevant matter for both countries, given the associated costs, monetary and health security-wise, of not addressing this situation at all. Also, detecting chronic and non-communicable diseases within the community has been crucial, although facilitating access to more specialized medical attention is something yet to be worked on. Milena Melo emphasizes this problem by arguing that "Federal policy classifies undocumented immigrants in the United States as ineligible for the majority of publicly funded healthcare services by virtue of their 'ilegal' status. As a result, those with chronic, debilitating illnesses struggle to find adequate treatment for severe conditions" (Melo, 2017, p. V). vDs at Mexican Consulates could detect the existence of chronic non-communicable diseases, such as diabetes, through free tests. The critical issue is that vDs do not provide treatment, only referrals to community clinics that could treat these conditions at a low cost.

Mexican consulates in the United States have diversified their services in numerous ways and domains, taking the lead on service provision for nationals abroad. Moreover, they have programs for mental and physical health, education, public insurance affiliation for non-migrant relatives, and even educational programs for secondgeneration immigrants (Délano, 2018). These efforts indicate that the Mexican government, according to the principle of shared responsibility, has invested in its diaspora and the services provided by vDs are a way of reaching out to vulnerable populations and keeping the community engaged. Furthermore, if preemptive healthcare is provided, there is a chance that protection cases may decrease, in which immigrants face a risk and need immediate assistance because of factors that could often be prevented. For the Mexican government, consular service provision is also symbolic, since it represents the State's interest in preserving the sense of belonging of their communities abroad and making them feel part of the State beyond borders. 
Along with Mexican communities living in the United States, Mexican returnees also constitute a group of concern. In 2017, 192334 Mexicans were returned by the Department of Homeland Security ([DHs], 2019), and there are no formal records about their health status. Furthermore, it has been documented that some immigrants that fall ill in the United States return for treatment in Mexico (Matus et al., 2016). Even though this subject of study is beyond the scope of the article, it is relevant in terms of framing the health of Mexicans and Americans as a binational issue, one that is embedded in the migration dynamics of both countries.

The U.s. healthcare system has for long been a topic of political debate and President Trump's controversial proposals have lit the fire, especially concerning immigrant populations. Although undocumented immigrants might be less prone to using emergency services or preventive healthcare provided by the state, the White House under Trump's administration has suggested all sorts of measures, from contesting the ACA in courts (Jost, 2018), to jeopardizing the legal status of low-income immigrants that benefit from government help in any way, including healthcare services (Puhl, 2019). Due to a long history of immigration, Mexican communities are well established and have strong ties to communities. Thus, as noted before, the number of first and second-generation Mexicans that reside in the United States is considerable, so the risks of depriving them from formal healthcare raise serious public health concerns (both, physical and mental). For instance, mixed status families composed of an immigrant family member with existing health conditions could turn down Medicaid out of fear of being considered a burden to the public health system. Another example is feeling undeserving of healthcare facilities, especially among immigrants with precarious status. These situations could endanger immigrant's health and increase the possibility of using emergency or private health services, which could result in a financial expense that the family unit may not be able to cover.

Undocumented immigrants usually cannot afford paying for costly treatments, especially when suffering from chronic and non-communicable diseases. For example, Milena Melo (2017) examined the treatment experiences of undocumented Mexican immigrants who suffered from end-stage renal disease (ESRD) in South Texas. At a twoyear fieldwork that included participant observation, semi-structured interviews, and case studies with 42 healthcare professionals and 100 Mexican-born dialysis patients (50 undocumented and 50 documented), she employed dialysis as an extreme case study, demonstrating the detrimental and fatal consequences that occur when access to healthcare is restricted or denied based upon citizenship and legal immigration status. Melo traced how undocumented immigrants with ESRD navigated the U.s. healthcare system, "which seeks to elude them in all but immediate, life-threatening emergencies, leaving them with only one viable option: to become a patient at risk of dying in order to maintain life" (Melo, 2017, p. V).

Melo blames the healthcare system, which prevents these seriously sick patients from receiving treatment, due to their inability to seek insurance or to pay for costly dialysis. She argues that the problem in the United States is that access to healthcare for undocumented immigrants is restricted by healthcare policies established at all levels: national, state, and institutional. Melo affirms that the majority of undocumented immigrants only have access to the healthcare system when they are able to pay themselves for their treatment, life-threatening condition or emergency situation. There are National healthcare policies, like EMTALA (Emergency Medical Treatment and Active Labor Act) and Emergency Medicaid, which provide access under emergency 
conditions to all patients, regardless of their immigration status or ability to pay for the services rendered. Also, Emergency Medicaid can be granted when:

a medical condition (including emergency labor and delivery) manifesting itself by acute symptoms of sufficient severity (including severe pain) such that the absence of immediate medical attention could reasonably be expected to result in-[así está el original, no preguntar] ( $a$ ) placing the patient's health in serious jeopardy, $(b)$ serious impairment to bodily functions, or $(c)$ serious dysfunction of any bodily organ or part. (Campbell et al., 2010, p. 185, cited in Melo, 2017, pp. 2-3).

However, according to this criterion the patient must be in a life or death state to qualify for services, like a ruptured appendix. Conditions rendered not emergent by the physician, such as kidney stones, can be turned away until they reach a life-threatening complication even if the patient will suffer discomfort in the meantime. Therefore, there are very few protections and limited resources for undocumented immigrants requiring continuous follow-up treatment for chronic and terminal diseases that are not immediately fatal (Melo, 2017, pp. 2-3). Additionally, the undocumented status prevents patients from paying for their treatment: "In 2010, a nationwide study found that the average cost for one year of dialysis covered by Medicare and/or insurance was $\$ 76906$ versus $\$ 284655$ for one year of emergency dialysis" (Campbell et al., 2010, cited in Melo, 2017, p. 3).

Undocumented immigrants with ESRD are excluded from out-patient, for-profit dialysis centers due to their uninsured status and inability to pay the costs for dialysis treatments three times a week. As a result, undocumented immigrants can only receive dialysis if they present to the emergency room and are deemed sick enough according to criteria set by hospital and state regulations. Not fulfilling this criterion means that patients are sent home and told to return to the hospital when they are in a life threatening situation.

The U.s. healthcare system, as structured by state and federal law, subjects undocumented ESRD patients to a power dynamic that oscillates between inclusion and exclusion. At the most basic level, these people are both treated and untreated, managed and unmanaged (Melo, 2017, pp. 3-4).

This is just an example of how hard it is to be an undocumented immigrant who suffers from a chronic non-communicable disease in the United States. Considering obstacles faced by immigrants to access healthcare in the United States, below, the importance of vDs and community health centers will be addressed.

\section{The Importance of the VDS Program and Community Clinics}

Due to changes in access to healthcare during the Obama and Trump administrations, community health centers have been crucial, as they have turned out to be the only source of health services at a reasonable price that are trusted when they are recommended within the same members of the community, and provide services in Spanish. Furthermore, in a context where urgent care for uninsured patients can become a financial burden for their families, preventive care services and early 
detection of chronic and non-communicable diseases should be vital within the uninsured community, although in some consulates they remain under-used by immigrant populations.

The Government of Mexico, through the Ministry of Health and the Ministry of Foreign Affairs, has set in place vDs within the 50 Consulates of Mexico in the United States. VDS aim to be fundamental in preserving the health of uninsured immigrants as they provide informational resources as well as basic screenings such as blood, sugar, cholesterol, body mass, sexually transmitted diseases (STD) tests, and vision tests. vDS also refer prospective patients to community health centers (Rangel et al., 2017; Rangel et al., 2016, p. 97; IME, 2016). In addition, there are two consular programs designed to serve the communities that live at considerable distances from the consulates or to approach locations where there is a high concentration of Mexicans, namely, Consulados sobre Ruedas (Consulates on Wheels) and Consulados Móviles (Mobile Consulates) (Secretaría de Relaciones Exteriores, 2014). Since the creation of the vDS program, bearing in mind a comprehensive service provision, the Government of Mexico has maked efforts in order to include health and other services through these consular programs, aside from their traditional main purpose of providing documentation services (passports and consular IDs mainly).

Consequently, the Mexican government, in alliance with community health centers, has provided opportunities to gain access to affordable healthcare services. These actions gain even more importance during the Trump administration, which has openly expressed that those who get into the public system will be a priority of deportation. Furthermore, the American Health Care Act (House of Representatives 1528), passed by the House of Representatives on May 4, 2017, continues to block access to affordable healthcare for undocumented population (The Henry J. Kaiser Family Foundation, 2017). Given the unwelcoming environment for immigrants fostered from the White House, advocates argue many documented residents and U.S. citizens are not accessing health care services, because of those pressures (Kennedy, 2018; J. Montenegro, personal communication, January 9, 2018). Daniel Bouton, a director at the Community Council, a nonprofit organization specialized in healthcare enrollment for low-income families based in Dallas, expressed that after Trump became president "every single day families canceled [their Medicaid plans and] ... people really didn't access any of our programs” (Kennedy, 2018).

Even though some nationals are still hesitant to use the services provided by community clinics, others do feel more confident after the consulate's referral. In this sense, services provided through the vDs are crucial for Mexican immigrants, as they come from an entity that will not disclose their immigration status, can refer them to clinics and other allies for further care, and provide culturally sensitive services in their language. Secondly, given the high costs of medical services in the United States, particularly for chronic and non-communicable diseases like diabetes and hypertension, vDs have a vital role in preemptive medicine and in detecting these diseases, hopefully, in their early stages.

Moreover, mental health is arising as a new demand of the Mexican communities in the United States. Immigrant populations are experiencing mental trauma and now, given the current anti-immigrant policies, legal and social pressure increased upon them, which has led them to need — and at times seek- mental healthcare, an issue that has come to the attention of consular officials (Vera, 2019). Even though Mexican consulates in the United States offer far more services than their counterparts in other 
continents, it is not the case when it comes to mental health provision. Interestingly enough, Mexican consulates in Germany, Great Britain and Ireland have Virtual Mental Health Windows (vMHw), an online platform that offers information to help Mexican immigrants identify if they have any symptom of psychological disorders in early stages. VMHW also contains the contact information of Spanish-speaking mental health experts located in Europe (Secretaría de Relaciones Exteriores, 2019). Although the profile of Mexican communities in Europe differs greatly from the ones in the United States, the implementation of vmHw is being considered in the United States. Actually, according to Evelyn Vera, a former public official at IME, the Government of Mexico launched a pilot project that turned out to be quite successful among users. Therefore, IME is considering implementing a non-virtual model in order to provide service for Mexicans that have little access to internet, do not have the technical skills to navigate online, or simply do not trust online services to share sensitive information and prefer a personalized service (E. Vera, personal communication, May 14, 2019).

Despite all the efforts, there are still challenges in providing more specialized services at an affordable price. The following analysis will evaluate the services that vDs have had on providing basic health services to uninsured Mexican immigrants in the 50 Consulates, and in particular in Texas, Arizona, Idaho, Montana, Nevada, Oregon and Florida.

\section{Case Analysis: the Mexican Consulates' Commitment in the Provision of Healthcare Services}

The vDs Program has a significant role in providing basic healthcare services to Mexican nationals abroad. According to the Mexican Ministry of Health, its main focus is to address problems such as drug abuse, arthritis, asthma and allergies, cancer, prenatal care, diabetes, heart diseases, STD, hypertension and influenza. The number of people served has been growing, making it almost a third of the undocumented Mexicans in the United States. According to Rangel et al. (2016), during 2015 the most important types of services offered by vDs in 50 states were as show in Table 1.

Table 1. Number of people and services in 50 vDs by type of service (2015)

\begin{tabular}{|l|r|}
\hline \multicolumn{1}{|c|}{ Population / Type of service } & Number \\
\hline Population served & 1525504 \\
\hline Total number of services (guidance/counseling) & 2453139 \\
\hline Total number of people in which detected an illness & 1462166 \\
\hline Total vaccinations & 63084 \\
\hline Total number of people who were referred to health services in the U.S. & 299806 \\
\hline Total number of people enrolled in healthcare in the U.S. & 24241 \\
\hline Total number of people served in Mobile Consulates & 252976 \\
\hline
\end{tabular}

Source: prepared by authors based on Rangel et al. (2016, p. 98-99). 
Table 1 shows that most of the vDs users already had a medical condition. Prevalence of the leading causes of morbidity within the Mexican community were: overweight and obesity, high pressure and high cholesterol (Rangel et al., 2016, p. 100). The majority of those served by the vDs asked for guidance and counseling more than once. This shows that although the focus is on the prevention side of illnesses, people with medical conditions were going to vDS as a way to find a solution for their health problems. Nevertheless, it is surprising to observe that only $20 \%$ of those who approached for counsel were actually referred to a clinic. Although speculative at this time, this might reveal that it is possible that the participants not referred to clinics were only curious about the services, that they might already be receiving medical attention or that they were reluctant to try to get help from other agencies. If this last possibility was true, it would mean that there is a real fear to go to other institutions to seek for medical services, given the political context in which there is a public policy that punishes the use of governmental aid.

Furthermore, the information of this study reveals that most of the people that are approaching vDS are uninsured. This demonstrates the importance of this program as it is probably the only source of medical services that Mexicans in the United States have access to. It is important to stress out that almost $17 \%$ of the persons served through vDs were seen in the Mobile Consulates. These are brought to distant places, away from the consular offices, that are usually characterized for their lack of services and connectivity to major cities.

The authors made an in-depth analysis for the cases of the Mexican Consulates in Boise, Idaho; McAllen, Texas; Miami, Florida; and, Phoenix, Arizona. It is important to mention that every consulate is responsible for a specific geographical area, which is the consulate's jurisdiction. The Mexican Consulate in Boise has jurisdiction over 37 counties in Idaho, 33 counties in Montana, four in Oregon and one in Nevada. The Mexican Consulate in McAllen is responsible for three counties in southern Texas. The Consulate in Miami has 13 counties in Florida and the one in Phoenix oversees seven counties in Arizona. A survey was applied within the above-referred consulates, in order to obtain information regarding the access of Mexican immigrants to healthcare services, and about the actions implemented by the Mexican consulates to promote this access in the context of Obamacare. The results for 2015 are shown in Table 2.

Table 2. Access to healthcare provided by four VDs in seven states (2015)

\begin{tabular}{|c|c|c|c|c|c|c|}
\hline State & Counties & $\begin{array}{c}\text { Total } \\
\text { population }\end{array}$ & $\begin{array}{c}\text { Mexican } \\
\text { population }\end{array}$ & $\begin{array}{l}\text { Persons seen } \\
\text { by the Health } \\
\text { Window }\end{array}$ & $\begin{array}{l}\text { \% without } \\
\text { coverage }\end{array}$ & Referrals \\
\hline Texas & 3 & 842960 & 758664 & 34709 & $70 \%$ & 33350 \\
\hline Arizona & 7 & 4724947 & 1700000 & 33645 & $70 \%$ & 1500 \\
\hline Idaho & 37 & 1612136 & 148923 & \multirow{4}{*}{10427} & \multirow{4}{*}{ N.A. } & \multirow{4}{*}{662} \\
\hline Montana & 33 & 1015165 & 20048 & & & \\
\hline Nevada & 1 & 52384 & 9951 & & & \\
\hline Oregon & 4 & 78963 & 10092 & & & \\
\hline Florida & 13 & 7500000 & 260000 & 12000 & $90 \%$ & N.A. \\
\hline
\end{tabular}

Source: prepared by authors based on information provided by Mexican Consulates in Boise, McAllen, Miami and Phoenix, 2015. 
The Mexican consulate in McAllen is a revealing case of the situation uninsured Mexicans are facing in the United States. In 2015, its jurisdiction comprised 842 960 persons, from which $90 \%$ were Mexican nationals. During 2015, the vDs gave attention to 34709 Mexicans; $70 \%$ of them had no insurance. This consulate is a small-scale demonstration of the high numbers of uninsured Mexicans in the United States. Furthermore, data from that vDs showed that 33350 persons needed to have more extensive health evaluation and were referred to community clinics. Data from the Mexican Consulate in Phoenix, Arizona, showed a similar pattern regarding the percentage of uninsured persons. In the seven counties that they served, the total population comprised 4724947 inhabitants, of which 35\% were Mexicans. During 2015, the Consulate assisted 6379 persons, and once again, $70 \%$ of them were uninsured. There were 1500 referrals to clinics.

In 2015, the Consulate of Mexico in Boise served a territory where 2758648 persons lived. From those, approximately 189014 were Hispanic. The Consulate's vDS provided assistance to 10427 persons and referred 662 to community-based clinics. In this case, unfortunately, there was no available information regarding the percentage of those who had insurance and those who did not. Nevertheless, it is interesting to observe that less than $10 \%$ of those who used the vDs required further medical services. Until now, there is no scientific evidence to explain these results. It might be that the population served by that vDs might have had other health issues still undetected; they might have had access to better food sources and therefore they were healthier; they might have had a health coverage of some other sort, or the health prevention campaigns were more effective. The answers to these hypotheses are left for a future analysis.

Finally, there is the case of the Consulate of Mexico in Miami. The total population in their area was 7500000 persons in 2015. There were approximately 260000 Mexicans in their circumscription. For the reviewed time frame, the Health Window assisted 12000 persons, of which 90\% did not have any type of insurance. However, there is no available information regarding the referrals to community clinics and therefore it is not possible to make any deductions regarding the health condition of those who were served by the Health Window.

Table 3 demonstrates that vDs in all four consulates offered a wide range of information regarding the most common health problems faced by Mexicans in the United States during 2015. In all four cases, the most common health issues were related to obesity, diabetes, high cholesterol levels, hypertension and cancer (all non-communicable diseases). The first four, also common health problems for the other 46 consulates (Rangel et al., 2016), might be associated to a diet rich in carbohydrates and with little nutrition value. Nutrition decisions might be influenced first by the family budget (high caloric foods tend to be less expensive than more balanced food options) and by the time constraints of the household's head, given that most of them have several jobs and they do not have time to cook healthy meals. Table 3 shows the link between the informational services and tests offered at the vDs and the most common health problems faced by Mexican immigrants in the United States. 
Table 3. Information and free tests provided at VDS to cope with the most common health problems (2015)

\begin{tabular}{|c|c|c|}
\hline $\begin{array}{l}\text { Information and/or } \\
\text { counseling }\end{array}$ & Free screenings & $\begin{array}{l}\text { Most common } \\
\text { health problems }\end{array}$ \\
\hline Health problems related with obesity & Weight, height and body mass & Obesity \\
\hline Diabetes & Glycemia & Diabetes \\
\hline Metabolism and cholesterol & Cholesterol and triglycerides & High cholesterol levels \\
\hline $\begin{array}{l}\text { Hypertension and cardiovascular } \\
\text { diseases }\end{array}$ & Blood pressure & Hypertension \\
\hline Cancer & Skin cancer detection & $\begin{array}{l}\text { Cancer (especially skin } \\
\text { cancer) }\end{array}$ \\
\hline Reproductive health & STD tests & \\
\hline Women's health & Mammograms & \\
\hline Influenza & Influenza vaccine & \\
\hline Dental hygiene & Odontology services & \\
\hline Others: & Others: & \\
\hline Drug abuse & Urine test & \\
\hline Occupational health & Tuberculosis test & \\
\hline Prenatal care & Herpes Zoster vaccine & \\
\hline \multicolumn{3}{|l|}{ Vision } \\
\hline \multicolumn{3}{|l|}{ Sports } \\
\hline Mental health & & \\
\hline
\end{tabular}

Source: prepared by authors based on information provided by Consulates of Mexico in Boise, McAllen, Miami and Phoenix, 2015.

Coinciding with the results of the surveys conducted, Rangel et al. (2016) explain that $53.8 \%$ of all services offered by the 50 vDs were guidance/counseling on chronic and non-communicable diseases (diabetes, obesity and cardiovascular diseases [hypertension]). Other themes addressed were women's health, mental health, 
substance abuse, family violence, birth control and health insurance. Coherently, the free tests provided by the $50 \mathrm{vDs}$, including the four vDs of our case study, have been oriented towards those health problems affecting most immigrants. Detection of health problems has been high: of the total of 142004 blood glucose measurements in 50 consulates, $23 \%$ evidenced high glucose levels and nearly half of participants that had their body mass index measured (48.6\% out of 85759 participants) were overweight or obese. Almost one third (30.3\% out of 130796 participants) recorded high pressure (over $130 \mathrm{mmHg}$ ) (Rangel et al., 2016, p. 98).

There is also coherence between the most serious conditions and free tests, such as free mammograms. Chronic non-communicable diseases, cardiovascular diseases and cancer were among the most common conditions of Mexicans in these four Consulates. Skin cancer is a common type of cancer as a consequence of exposure to the sunrays. This could be related to exposure to uv rays while crossing the desert between Mexico and the United States and labor activities in fields. In further investigations, it would be interesting to analyze the prevalence of skin cancer in border states, such as Arizona and Texas, which were part of our survey.

With the sample of four consulates examined, it could be argued that vDs have played an important role in providing healthcare for Mexicans in the United States. Two pieces of information derived from our survey are crucial: on the one hand, the number of uninsured participants is striking; on the other hand, diabetes, overweight, hypertension and cancer should be health priority issues that need further attention. It is important that vDs continue to offer counseling and guidance on affordable insurance options. If participants cannot afford to buy a private insurance and are undocumented, it is fundamental that they have referrals to community clinics that immigrants can trust, reassuring them that there is no fear of deportation if they are treated for any medical condition. If Mexican nationals return to the country, then more permanent access to public health programs in Mexico must be secured.

Below, a review of the performance of vDs in 2015 will be presented as well as recommendations for the Mexican government. We also include questions for further research on this topic.

\section{Public Policy Recommendations}

Based on the literature review, on data obtained from interviews, on statistics provided by 50 vDs and data submitted by four particular ones in seven states, we propose the following public policy recommendations:

1. Only $20 \%$ of those who approached for counsel at 50 vDs in 2015 were actually referred to a clinic. This number may decrease during the Trump administration as immigrants may be more fearful of consulting a doctor. Thus, the vDs staff has to come up with creative ways to reassure immigrants that the health clinics where they would be referred to are trustworthy. The testimony of other immigrants might be reassuring for this purpose.

2. Most immigrants already had a medical condition before approaching a vDS, which means that they are not quite fulfilling their preemptive goal. This may be for various reasons. As stated above, one of them might be the lack of information about services provided by the consulates. Besides increasing the advertising 
of their services in mass media and social networks, consulates should also work on building trust with the immigrants they assist, especially in protection and documentation cases, which are the services immigrants use more regularly. If immigrants are satisfied with these services, they will be more likely to use other services and approach the consulates on a regular basis. Also, there might be the need to widen the scope of the vDs's vocation to promote the early detection of chronic diseases; it will be crucial to have the allies to refer those who are already sick for medical attention.

3. It would be helpful to standardize data-gathering methodologies at vDs. Data collection is important because it could inform public policies and decision-making processes regarding new services needed by the population in specific areas.

4. Given the specific vulnerabilities of immigrant populations and the anti-immigrant political rhetoric of current times, immigrants are more prone to suffer from mental health disorders. Thus, consulates should consider expanding the services of vDs to offer assistance related to mental health, both, virtually and face-to-face.

5. Skin cancer has been detected as a common health problem in border states, such as Arizona and Texas. It would be important to conduct further research on this topic, in order to analyze the impact on cancer prevalence of prolonged exposure to sun rays on the journey through the desert between Mexico and the United States and from long hours working in the fields under the sunrays. This leads us to think that further and detailed analysis of health problems in each consulate would be helpful in order to know specificities for each consular jurisdiction.

6. The Mexican diaspora is a heterogeneous one; thus, there is a need to address different healthcare issues for different groups. Although some consulates already provide gender-specific advice on health, other groups such as LGBTTI+, children and indigenous populations may also require specialized assistance concerning physical and mental health.

7. Returning population, although beyond the scope of this article, should also be considered. Along with those who are deported, many Mexicans also return when they already have a health condition and are in urgent need to receive formal healthcare (Mines et al., 2010). Thus, emphasizing the actions regarding preemptive healthcare while they are in the United States may reduce the costs of their treatment back in Mexico.

8. In the future, it would be interesting to explore new methods of attention at vDS, beyond the provision of guidance/counseling, free tests and referrals to community clinics. The feasibility of assisting patients through the use of telemedicine could be analyzed. Some online service methods are already in place. For instance, through the app miconsulmex, Mexicans living in the United States can be informed about the services and activities of the consulates nearest to them. These tools should be thought of as a reference for virtual healthcare services. Regardless of the success of virtual methods, the face-to-face service should be preserved, given that not all members of the diaspora will be willing or able to use online services. Collaboration with Mexican institutions, along with the use of telemedicine, could also be beneficial; for example, by contacting doctors in Mexico that work in the public sector, and arranging online appointments. Then, Mexican patients in the United States, enrolled in some Mexican public health program, would not need to travel to Mexico in order to be treated or get 
counseling. This innovation could have positive results for returned immigrants as well, since they would not have to interrupt medical treatment upon return. However, this recommendation may not be easy to achieve, due to the costly implementation of such practice. Nevertheless, telemedicine may be a tool to explore in the future, as it breaks physical barriers and increases the possibilities of treating and offering more guidance and counseling to patients. Telemedicine would have another benefit: fearful patients in the United States would be more willing to trust a doctor that is based in Mexico than one that is in the United States at a facility that asks for patients' information. Some legal considerations must be addressed as well, such as the possibility to practice medicine in another country, or even malpractice cases (although consulates are legally considered an extension of the Mexican territory). Some of the matters yet to be resolved are innovative ways to cover some minimal fees and arrangements on how would patients receive medicines or have access to more advanced health screenings.

\section{Discussion}

Healthcare and immigration patterns are not to be taken separately when discussing Mexican and American populations. As shown in the text, immigration laws and their effects, — such as difficulties navigating the system and fear of being deported for using healthcare services - have enormous repercussions for immigrants, their families and communities. Not only are immigration and healthcare laws relevant for immigrants' well-being, but we must also consider that anti-immigrant sentiments have a stressful effect among the population of immigrant origin, and sometimes, they might have stronger repercussions on their everyday lives. Since this article refers to a binational population, government and civil society in both countries should address immigrants' healthcare.

The health system in the United States is becoming harder to access for immigrants; immigration laws, anti-immigrant policies, along with a potential reform to the whole immigration and healthcare systems put Mexican immigrants at risk. Even though the ACA was intended to broaden the spectrum of persons covered by an affordable healthcare plan, immigrants, particularly undocumented ones, were left without a source of affordable health plans.

Fear of visiting a doctor will also have an impact on prevention and early detection of chronic and non-communicable diseases among undocumented immigrants. This poses serious risks among the immigrant community because people might not be addressing incipient health problems, nor practicing routine exams due to the costs of receiving medical services and the fear of having somebody in the family deported. If there is no preventive care, immigrants will be more likely to end up at an Emergency Room, and that will result not only in higher costs, but also in irreversible health conditions. Another risk is the expansion of infectious diseases and other public health problems, since people skip vaccination schedules or do not treat infectious diseases in a timely manner. Prevalence of non-treated chronic and non-communicable diseases, such as diabetes, obesity, overweight, hypertension or cancer is also expected. Furthermore, mental health disorders are, now more than ever, a concern for Mexican communities in the United States and an important issue on IME's agenda. 
In this context, community health suppliers become key players offering critical sources of information and preventive screenings. The last Mexican administrations have provided outreach to the Mexican community in the United States through vDS operating in its 50 Consulates in that nation, delivering information, free tests and referring prospective patients to community clinics. As it was discussed here, the four consulates reviewed identified immigrants with health problems that required additional attention. Moreover, vDs have established a network of allies that have helped to address the most common health problems of these Mexicans in need of further health assistance. Unfortunately, it is complicated to track immigrants' health evolution once they have been referred to health suppliers.

Although there have been some efforts provided by the Mexican State to increase access to healthcare in the United States, to date, it has not been possible to assist all Mexicans living in the neighboring country, given that not all of them go to their consulates for health services and referrals to clinics. This may be because Mexican immigrants are not in the habit of taking preventive actions, they do not have enough time to attend VDs, or they might not know that this service is available to them. Consequently, Mexican consulates need to increase efforts to make their constituency aware of the health services that are available at the consulates through their vDs, and to work on the preventive side of healthcare. Most Mexicans approach the consulates for the first time because they need documents (such as birth certificates or passports), or because they are seeking legal advice. The consulate's staff uses these visits to promote other consular services and provide helpful information, such as the one related to health.

Prevention of health problems and early detection of illnesses are also associated with the availability of information, especially on the most common diseases already identified in every vDS. To achieve these goals, vDs must continue to reach out to the community through other means, such as radio, T.V. and social media spots both in English and Spanish and even in indigenous languages where needed. Consulates must also widen their areas of influence to include places in which the immigrant community is located, in order to deliver the message of healthy habits, especially through Mobile Consulates and Consulates on Wheels.

vDs have been decisive in offering Mexican immigrants access to healthcare services in a context in which costs are one of the main obstacles to receiving medical services, along with other disadvantages such as lack of knowledge to navigate the system, and mistrust due to irregular immigration status. However, this job is still unfinished. The services offered by VDS are limited and cannot address nor follow up on the cases of those who are seriously ill. Therefore, vDs must continue to strengthen their alliances and search for new ones in order to have a network of healthcare providers that can help these uninsured patients. After having identified the main health problems within the community that they serve, vDs must concentrate on making more widely available guidance, tests and treatments for the most common health conditions. With these actions, the exclusionary effects of the healthcare system in the United States could be diminished. 


\section{Conclusions}

The U.S. healthcare system, as analyzed here, has been modified during the Obama and Trump administrations. There are positive aspects derived from ACA, especially the fact that more citizens got health insurance. Nevertheless, undocumented immigrants were excluded from having the possibility of accessing both public and private insurance, as they need a Social Security Number to be enrolled. Moreover, undocumented immigrants lack the money to pay for costly treatments, not only at the prevention level, but also to treat chronic and non-communicable diseases. For documented immigrants, fear of being enrolled, especially during the Trump administration, is also generating disenrollment from public services in order to avoid being considered a public charge for the government. Naturally, this has impacts on their health and increases the chances of ending in an Emergency Room aside from the possibility of giving it to others.

As explained above, vDs provide reliable and affordable access to basic healthcare services for Mexican immigrants in the United States, especially for the undocumented. However, it is also clear that economic and personal resources are scarce. In further studies it would be interesting to conduct field work at Mexican consulates in the United States in order to ask documented and undocumented Mexican immigrants how trustworthy they find these services provided by vDs and community clinics. Such a study could reveal the level of trust Mexicans have in these clinics when being referred by consulates.

Given the current political context in both countries, the discussion of healthcare and immigration in a binational perspective is most necessary. Indeed, there is a fair amount of uncertainty at both sides of the border, but uncertainty can also mean possibility, that is, new partnerships, solidarity among binational communities and the strengthening of Mexican consular services.

\section{References}

Adams, R. (2018). Immigration Crackdown Raises Fears of Seeking Health Care. https:/ / www. rollcall.com/news/politics/immigration-crackdown-raises-fears-seeking-health-care

Amadeo, K. (2018). Donald Trump on Health Care How Trump's Health Care Policies Will Raise Premium Prices for You. https://www.thebalance.com/how-could-trumpchange-health-care-in-america-4111422

American Psychological Association (APA). (2018). Stress in America. Generation Z. https://www.apa.org/news/press/releases/stress

Barnett, J. C. \& Vomovitsky, M. (2016). Health Insurance Coverage in the United States 2015. U. S. Department of Health and Human Services. https:/ / minorityhealth. hhs.gov/omh/browse.aspx?lvl=3\&lvlid=64

Becerra, D., Androff, D. K., Ayón, C. \& Castillo, J. T. (2012). Fear vs. Facts: Examining the Economic Impact of Undocumented Immigrants in the U.S. Journal of Sociology and Social Welfare, 39(4), 111-135. 
Campbell, G. A., Sanoff, S. \& Rosner, M. H. (2010). Care of the Undocumented Immigrant in the United States with ESRD. American Journal of Kidney Diseases, 55(1), 181-191. https://doi.org/10.1053/j.ajkd.2009.06.039

Castañeda, H. \& Melo, M. A. (2014). Health Care Access for Latino Mixed-Status Families: Barriers, Strategies, and Implications for Reform. American Behavioral Scientist, 58(14).

Chen, J., Vargas-Bustamante, A., Mortensen, K. \& Ortega, A. N. (2016). Racial and Ethnic Disparities in Health Care Access and Utilization under the Affordable Care Act. Medical Care, 54(2), 140-146.

Consejo Nacional de Población. (2012). Migración y salud. Jóvenes mexicanos inmigrantes en Estados Unidos. Secretaría de Gobernación. http://www.conapo.gob.mx/ en/CONAPO/Migracion_y_Salud_Jovenes_inmigrantes_mexicanos_en_Estados_Unidos

Consulado General en Little Rock. (2019). Ventanillas de Salud. Secretaría de Relaciones Exteriores. https://consulmex.sre.gob.mx/littlerock/index.php/proteccion/ventanillas-de-salud

Consulado General en Nueva York. (2019). Ventanilla de Salud. Secretaría de Relaciones Exteriores. https://consulmex.sre.gob.mx/nuevayork/index.php/espa$\mathrm{nol} /$ programas/ventanilla-de-salud

Consumer News and Business Channel (CNBC). (2018, February 9). Trump Administration May Make It Harder for Immigrants Who Use Public Benefits. https:/ / www.cnbc. com/2018/02/09/trump-administration-may-target-immigrants-who-use-foodaid-other-benefits.html

Délano, A. (2018). From Here and There: Diaspora Policies, Integration and Social Rights Beyond Borders. Oxford University Press.

Department of Homeland Security (DHS). (2019). Annual Report. Migration Enforcement Actions 2017. https://www.dhs.gov/immigration-statistics/enforcement-actions

Department of Homeland Security v. New York. (2020, January 20). 589 U. S. 2020. https://www.supremecourt.gov/opinions/19pdf/19a785_j4ek.pdf

General Assembly. (1948). Universal Declaration of Human Rights. United Nations. https://undocs.org/en/A/PV.183

General Assembly. (2015). Transforming our World: The 2030 Agenda for Sustainable Development. United Nations. https://undocs.org/en/A/RES/70/1

Gómez, O., Sesma, S., Becerril, V., Knaul, F. M., Arreola, H. \& Frenk, J. (2011). Sistema de salud de México. Salud Pública de México, 53. http://saludpublica.mx/index. $\mathrm{php} / \mathrm{spm} /$ article/view/5043/10023

Gzesh, S. \& Schiavon, J. A. (2018). La protección consular mexicana ante la administración Trump: Recomendaciones de acción inmediata (Documentos de Política Migratoria 02). CIDE, El Colegio de México, PUed-unam y Fundación Vidanta. https://migdep.colmex.mx/publicaciones/DPM-02.pdf

Hernández, D. (2015). Protección consular mexicana. Miguel Ángel Porrúa.

Instituto de los Mexicanos en el Exterior (IME). (2016). Ventanilla de Salud. https:// www.gob.mx/ime/acciones-y-programas/ventanilla-de-salud 
Jost, T. (2018). The Affordable Care Act under the Trump Administration. https://www.commonwealthfund.org/blog/2018/affordable-care-act-under-trump-administration

Kemmick, J., Alcalá, H. E., Roby, D. H., Grande, D. T., Alberto, C. K., McKenna, R. M. \& Ortega, A. N. (2019). Disparities in Pediatric Provider Availability by Insurance Type After the ACA in California. Academic Pediatrics, 19(3), 325-332. https:// doi.org/10.1016/j.acap.2018.09.003

Kennedy, K. (2018, January 21). Deportation Fears Have Legal Immigrants Avoiding Health Care. Associated Press News. http://www.apnewsarchive.com/2018/Deportation_fears_have_legal_immigrants_avoiding_health_care/id-9f893855e49143baad9c96816ec8f731

Luthi, S. (2020, January 28). Supreme Court Allows Trump to Enforce 'Public Charge' Immigration Rule. The Justices Lifted a Nationwide Injunction Against a Sweeping Policy Targeting Poor Immigrants. Politico. https://www.politico.com/ news/2020/01/27/supreme-court-enforce-trump-immigration-rule-106520

Martínez, A. D., Ruelas, L. \& Granger, D. A. (2018). Household Fear of Deportation in Relation to Chronic Stressors and Salivary Proinflammatory Cytokines in Mexican-Origin Families Post-SB 1070. SSM-Population Health, 5, 188-200.

Matus, M., Ramírez, R. Castillo, E. \& Cariño, G. L. (2016). Salud mental y tecnologías móviles en comunidades indígenas transnacionales. Frontera Norte, 28(56) 135-163.

Melo, M. A. (2017). Enacting Life: Dialysis Among Undocumented Mexican Immigrants in the U.S.-Mexico Borderlands (Dissertation for doctor degree). University of Texas at San Antonio. ProQuest, 10619059.

Merriam-Webster. (n. d.). Generation Z. https://www.merriam-webster.com/dictionary/Generation $\% 20 \mathrm{Z}$

Mines, R., Nichols, S. \& Runsten, D. (2010). California's Indigenous Farmworkers. Final Report of the Indigenous Farmworker Study (IFS). http://www.indigenousfarmworkers.org/IFS\%20Full\%20Report\%20_Jan2010.pdf

Mosler, E., Dag, J. \& Laczko, F. (2018). Global Migration Indicators 2018: Insights from the Global Migration Data Portal. Berlin: Global Migration Data Analysis Centre (GMDAC), International Organization for Migration. https://publications.iom. int/system/files/pdf/global_migration_indicators_2018.pdf

Moya, L., Ayón, C. \& Gurrola, M. (2013). Estamos Traumados: The Effect of Anti-Immigrant Sentiment and Policies on the Mental Health of Mexican Immigrant Families. Journal of Community Psychology, 41(8), 1005-1020.

Obamacare Facts (2018). Obamacare Facts: Facts on the Affordable Care Act. http:/ / obamacarefacts.com/obamacare-facts/

Office of the Assistant Secretary for Planning and Evaluation (ASPE). (2016). Impacts of the Affordable Care Act's Medicaid Expansion on Insurance Coverage and Access to Care. ASPE Issue Brief. https://aspe.hhs.gov/sites/default/files/ pdf/205141/medicaidexpansion.pdf

Office of the High Commissioner for Human Rights (онсHR). (1966). International Covenant on Economic, Social and Cultural Rights. Pub. L. No. Resolution 2200A (XXI). United Nations.

Organization for Economic Cooperation and Development (OECD). (2019a). Health at a Glance 2019. https://www.oecd-ilibrary.org/sites/4dd50c09-en/1/1/1/ index.html?itemId=/content/publication /4dd50c09-en\&mimeType=text/ 
html\&_csp_=82587932df7c06a6a3f9dab95304095d\&itemIGO=oecd\&itemContentType=book\#foreword-d1e15

Organization for Economic Cooperation and Development (OECD). (2019b). El gasto en salud superará el crecimiento del PIB en 2030. https://www.oecd.org/centrodemexico/medios/elgastoensaludsuperaraelcrecimientodelpiben2030.htm

Ortega, A. N., McKenna, R. M., Chen, J., Alcalá, H. E., Langellier, B. A. \& Roby, D. H. (2017). Insurance Coverage and Well-Child Visits Improved for Youth under the Affordable Care Act, but Latino Youth Still Lag Behind. Academic Pediatrics. https://doi.org/10.1016/j.acap.2017.07.006

Pan American Health Organization (РАно). (2018). Health of Refugees and Migrants: Regional Situation Analysis, Practices, Experiences, Lessons Learned and Ways Forward. World Health Organization.

Parmet, W. E. (2018, January 18). Immigration and Health Care under the Trump Administration. Health Affairs. https://www.healthaffairs.org/do/10.1377/ hblog20180105.259433/full/

Protecting Immigrant Families. (2019, April 18). Trump's Public Charge Proposal is Hurting Immigrant Families Now. Even Though DHS's Proposed Regulation is Not Final. https://protectingimmigrantfamilies.org/wp-content/uploads/2019/05/PIFDocumenting-Harm-Fact-Sheet-Final-4.18.19.pdf

Puhl, E. (2019). Totality of the Circumstances: Assessing the Public Charge Ground of Inadmissibility. Immigrant Legal Resource Center. https://www.ilrc.org/sites/default/ files/resources/total_circum_assess_pub_charge_inadmis-20190503.pdf

Rangel, M. G., Tonda, J., Zapata, G. R., Flynn, M., Gany, F., Lara J., Shapiro, I. \& Rosales, C. B. (2017). Ventanillas de Salud: A Collaborative and Binational Health Access and Preventive Care Program. Frontiers in Public Health. https://doi. org/10.3389/fpubh.2017.00151

Rangel, M. G., Zapata, R., González, J. E., Tonda, J. \& Cortés, P. (2016). Ventanillas de Salud: A Program Designed to Improve the Health of Mexican Immigrants Living in the United States. Migración y Salud, 95-102.

Rodríguez, R. (2014): Metodología de la Investigación. McGraw Hill.

Secretaría de Relaciones Exteriores. (2014). Normas para la realización del programa de consulados móviles en sus modalidades de "Consulados móviles", "Jornadas sabatinas, dominicales o en días inhábiles", "Consulados sobre ruedas" y "Actividades de documentación entre semana fuera de la oficina consular". https://sre.gob.mx/images/stories/docnormateca/dgsc/2014/norm2801.pdf

Secretaría de Relaciones Exteriores. (2019). Ventanilla Virtual de Salud Mental. https://embamex.sre.gob.mx/alemania/index.php/es/proteccion-consular/ ventanilla

The Henry J. Kaiser Family Foundation. (2013). Key Facts on Health Coverage for Low-Income Immigrants Today and Under the Affordable Care Act. http://kff.org/disparities-policy/fact-sheet/key-facts-on-health-coverage-for-low/

The Henry J. Kaiser Family Foundation. (2017). Summary of the American Health Care Act. http:/ / files.kff.org/attachment/Proposals-to-Replace-the-Affordable-CareAct-Summary-of-the-American-Health-Care-Act 
United Nations (un). (2018). Global Compact for Safe, Orderly and Regular Migration. https://refugeesmigrants.un.org/sites/default/files/180713_agreed_outcome_global_compact_for_migration.pdf

U.S. Citizen and Immigration Services. (2019). Final Rule on Public Charge Ground of Inadmissibility. https://www.uscis.gov/legal-resources/final-rule-public-charge-ground-inadmissibility

U.S. Department of Health and Human Services. (2015). What is the Difference Between Medicare and Medicaid? http://www.hhs.gov/answers/medicare-and-medicaid/ what-is-the-difference-between-medicare-medicaid/index.html

U.S. Department of Health and Human Services. (2019). (Formal communication issued on March 5, 2019). https://delauro.house.gov/sites/delauro.house.gov/ files/HHS_UAC_Reallocation_352019.pdf

Valdovinos, R.. (2019, May 13). Paper Presented at Primer Coloquio de Estudios sobre Diásporas, Roundtable 2 "Ejercicio transnacional de derechos sociales y políticos". Universidad Iberoamericana at Mexico City and El Colef.

Valle, V. M. \& Ortiz, C. B. (2015). Mexican Immigrants' Access to Healthcare on the U.S.-Mexican Border. Voices of Mexico, 100 (Special Section). http://www.revistascisan.unam.mx/Voices/pdfs/10022.pdf

Vera, E. (2019, May 14). Paper presented at Primer Coloquio de Estudios sobre Diásporas, Roundtable 4: "Políticas públicas y buenas prácticas". Universidad Iberoamericana at Mexico City and El Colef.

White House. (2017, January 25). Executive Order: Enhancing Public Safety in the Interior of the United States. https://www.whitehouse.gov/presidential-actions/executive-order-enhancing-public-safety-interior-united-states/

Valeria Marina Valle

Mexican, originally from Argentina. PhD. in Political and Social Sciences with orientation in International Relations, Master in Studies in International Relations from the Universidad Nacional Autónoma de México (UNAM) and Bachelor in International Relations from the Universidad del Salvador, Argentina. Academic of the Department of International Studies of the Universidad Iberoamericana, Mexico City (UIA). Member of the SNI, level 1. Research lines: migration and health, international cooperation for development, security, state-diaspora relations and protection mechanisms. Recent publication: Valle, V. M. (2016). An Assessment of Canada's Healthcare System. Weighing Achievements and Challenges. Norteamérica, 11(2), 193-217.

Wilma Laura Gandoy Vázquez

Mexican. Master in International Law and Bachelor in International Relations from Tecnológico de Monterrey, Mexico City Campus. Member of the Mexican Foreign Service career since 2012 and currently assigned as a Consul for Protection at the Consulate General of Mexico in San Francisco. Research lines: consular protection and assistance to the Mexican community in the United States. Recent publication: Gandoy, W. L. (2019). Atención consular con perspectiva de género. Siempre. http:// www.siempre.mx/2019/03/atencion-consular-con-perspectiva-de-genero/ 
Karla Angélica Valenzuela Moreno

Mexican. Doctor in Social and Political Sciences from the Universidad Iberoamericana and Master in Migration and Human Settlements from the University of Ryerson. Researcher at the Universidad Iberoamericana, Mexico City, coordinator of the Master's Degree in Migration Studies and member of the SNI. Research lines: security, state-diaspora relations and protection mechanisms. Recent publication: Valenzuela, K. A. (2019). Los consulados mexicanos en Estados Unidos: una aproximación desde la protección social. Interdisciplina, 7(18), 59-79. 